Univerzitet u Beogradu
Poljoprivredni fakultet
Institut za poljoprivrednu tehniku
Naučni časopis
POLJOPRIVREDNA TEHNIKA
Godina XLIII
Broj 4, 2018.
Strane: $8-12$

\title{
INTERNAL AND EXTERNAL AUDIT AS A FACTOR IN IMPROVING THE MANAGEMENT OF THE AGRICULTURAL ENTERPRISE
}

\author{
Popović Slobodan ${ }^{* 1}$, Laban Bogdan ${ }^{2}$, Vukasović Dragan ${ }^{3}$, \\ Ivić Mladen ${ }^{4}$, Nastić Sanda ${ }^{5}$, Vera Popović ${ }^{6}$ \\ ${ }^{1}$ Assistant Professor, Internal Auditor, Department of Management and Finance, \\ Faculty of Economics and Engineering Management, Cvećarska 2, Novi Sad, Serbia, \\ ${ }^{2} \mathrm{PhD}$, City administration of the City Subotica, Trg Slobode 1, \\ 24000 Subotica, Serbia \\ ${ }^{3}$ Associate Professor, Independent University of Banja Luka, Veljka Mlađenovića 12e, \\ 78000 Banja Luka, Bosnia and Hercegovina, \\ ${ }^{4}$ Associate Professor, University of Business Engineering and Management Banja Luka, \\ Faculty of Economics, 78000 Banja Luka, Bosnia and Hercegovina \\ ${ }^{5}$ PhD, JKP Vodovod i kanalizacija, Masarikova 17, 21000 Novi Sad, R.Serbia \\ ${ }^{6} \mathrm{PhD}$, Institute of Field and Vegetable Crops, M. Gorkog 30, 21000 Novi Sad, R.Serbia
}

\begin{abstract}
An audit may be a factor and a decision support mechanism for the management is set up. This time the use of the revision should contribute to improving the overall management results of the agricultural enterprise. The main objective of applying the recommendations of internal and external audit is to reduce the risk to the enterprise at all levels of governance. The paper emphasizes the importance of establishing a process of control mechanisms, which will increase the safety and security of business operations. The overall audit can provide full support to the management structure in the efforts to increase the safety and efficiency of operations, which is important in the agricultural sector, since it has a slow turnover of capital. The authors point out that there is no generally accepted model of implementation of management's behavior regarding the practical application of audit jobs that can be introduced in order to increase the efficiency of the company's operations.
\end{abstract}

\footnotetext{
${ }^{*} 1$ Corresponding autor. E-mail address: slobodan.popovic49@gmail.com
} 
In this way, the authors emphasize the importance of implementing the audit in agriculture, since they can benefit from the acceptance of audit conclusions.

Keywords: internal audit, external audit, management, results.

\section{INTRODUCTION}

A comprehensive review of agricultural production [1] should indicate some of the key economic governance factors $[2,3,4,5]$ in order to achieve increased effects. This is particularly important in agriculture as a low accumulative activity. By this, the essential authors draw attention to the complete management of the company, which is in accordance with already outlined management positions that we encounter in several authors $[6,7]$.

Essential authors draw attention to managerial observation of the company, where there are certainly places for the application of non-standard ways of improvement, such as internal and external audit, as a method of management and application of recommendations that can give benefits to the agricultural enterprise $[8,9,10]$.

Modern management is oriented to meeting the criteria of the "leader" of management [11], and the overall process can also contribute to the appreciation of attitudes of internal and external auditors. This essentially refers to large enterprises, such as agrarian enterprises [12], as well as corporations [13, 14].

Adherence to the recommendations of internal auditors by management is vital in the practical functioning of enterprises [15]. Accordingly, internal audit and control mechanisms can substantially reduce the risk intervals in a transitional country on the road to the EU.

\section{MATERIAL AND METHODS}

In order to increase security and reporting, the authors set the pivotal research of top management that was conducted in 30 randomly selected medium-sized enterprises in the Republic of Serbia, based on the agricultural business activity.

The aim was to determine the increase in the number of quality reporting of the lower levels to the management of the company. Authors point out that a larger number of reporting means greater security of reporting, but also increases total costs per individual enterprise.

Reporting costs arise from the greater involvement of permanently employed workers in internal audit activities and costs arising from the engagement of external auditors.

\section{RESULTS AND DISCUSSION}

In order to confirm the results of the research, the authors conducted an interview with top management. After processing the results obtained through a research interview, i.e. a survey, the authors present the results in two basic tables. 
The first gives an overview of the results in relation to the number of management top management reports in relation to the perceived risk expressed in nominal terms as shown in table 1 by the authors.

Table 1. Reporting ratio according to the number of reports relative to the estimated risk

\begin{tabular}{|c|c|c|c|}
\hline $\begin{array}{l}\text { Number of top } \\
\text { Management Reports }\end{array}$ & $\begin{array}{l}\text { Estimated risk } \\
\text { expressed in } \\
\text { nominal terms }\end{array}$ & Risk interval & $\begin{array}{l}\text { Nominal Risk in } \\
\text { Testing Enterprises }\end{array}$ \\
\hline 1 & 6 & $1-10$ & 174 \\
\hline 2 & 4 & $1-10$ & 115 \\
\hline 3 & 3 & $1-10$ & 87 \\
\hline 4 & 2 & $1-10$ & 59 \\
\hline
\end{tabular}

In the continuation of the research, the author's subject was to present the 10 highest-ranking risks per enterprise in agricultural enterprises. This was done by giving Table 5 nominally the highest-ranking risk of corporate governance.

In Table 3, the authors presented a list of other risks per enterprise. This is why the authors essentially pointed out the 10 most nominally ranked risks for the company, which can essentially have an impact on the company in the agrarian sector of the Republic of Serbia.

Table 2. Risk presentation at nominally highest risk per enterprise

\begin{tabular}{|c|l|c|c|}
\hline $\begin{array}{l}\text { Serial } \\
\text { number }\end{array}$ & $\begin{array}{l}\text { Basic risks (possible } \\
\text { identification) }\end{array}$ & Risk interval & $\begin{array}{l}\text { Nominal Risk in } \\
\text { Testing Enterprises }\end{array}$ \\
\hline 1 & Company's financial risk & $1-10$ & 180 \\
\hline 2 & $\begin{array}{l}\text { Risk related to management by } \\
\text { management }\end{array}$ & $1-10$ & 175 \\
\hline 3 & Strategic risk & $1-10$ & 148 \\
\hline 4 & Company's regulatory risk & $1-10$ & 136 \\
\hline 5 & $\begin{array}{l}\text { Technological risk associated } \\
\text { with the company's business }\end{array}$ & $1-10$ & 138 \\
\hline
\end{tabular}

Table 3. Display of other risks at nominal risk per enterprise

\begin{tabular}{|c|l|c|c|}
\hline $\begin{array}{l}\text { Serial } \\
\text { number }\end{array}$ & Other risks & Risk interval & $\begin{array}{l}\text { Nominal Risk in } \\
\text { Testing Enterprises }\end{array}$ \\
\hline 1 & Company's financial risk & $1-10$ & 100 \\
\hline 2 & $\begin{array}{l}\text { Risk related to management by } \\
\text { management }\end{array}$ & $1-10$ & 88 \\
\hline 3 & Strategic risk & $1-10$ & 82 \\
\hline 4 & Company's regulatory risk & $1-10$ & 65 \\
\hline 5 & $\begin{array}{l}\text { Technological risk associated } \\
\text { with the company's business }\end{array}$ & $1-10$ & 59 \\
\hline
\end{tabular}




\section{CONCLUSIONS}

Identifying the risks that the management can receive from internal and external audit in agricultural enterprises in transition countries such as the Republic of Serbia is of great importance for the management of these enterprises.

This indicates the importance of finding the most optimal processes in the company. In this paper, one way of fulfilling more criteria of optimum is presented, that is, the authors pointed out after testing for the importance of identifying important risks.

The authors emphasize the importance of ranking the risk interval, in this paper the authors pointed to possible ranking in the interval 1-10 on the example of 30 tested agricultural enterprises. The authors point out that these are not the only possible ones, but only the presentation of some of whom the authors pointed out by 5 grades and 5 other nominally highest-ranking risks.

The aim of this study was to highlight the importance of finding an interval of risk by an internal audit and an external audit in order to optimize corporate governance. This can achieve agro-economic benefits from the management that manages companies in the field of agriculture. In addition, this study can serve as a basis for new research in a large number of small and medium-sized enterprises, primarily in the field of agriculture.

\section{REFERENCES}

[1] Popović., S. 2014. Socio-ekonomski faktori ograničenja razvoja agrara, Monografija, Fimek, Novi Sad, p 30.

[2] Popović, S., Novaković, S., Đuranović, D., Mijić, R., Grublješić, Ž., Aničić, J. \& Majstorović, A. 2017. Application of international accounting standard-16 in a public company with predominantly agricultural activities, Economic Research-Ekonomska Istraživanja, Vol. 30, No. 1, 1850-1864.

[3] Flecher, K. 2003. Upravljanje marketingom i IT, Klio, Beograd, p 27.

[4] Holcher, J. 2011. Twenty years of economic transition: Success and Failures, The Journal of competitive economic studies, p 15.

[5] Popović S, Jovin S, Đuranović D, Popović V, Filipović V, Munitlak-Ivanović O, Grublješić Ž, Mijić R. 2017b. The Importance of Planting Pot Marigolds (Calendula officinalis L.) in degraded public spaces from the agroecological and economic perspective. Contemporary Agriculture, 66(1-2): 27-31.

[6] Hisrich, D.R., Peters, P.M., Shepherd, A. D. 2011. Preduzetništvo, Mate, Zagreb.

[7] Greuning, H. 2006. Međunarodni standardi finansijskog izveštavanja, Mate, Beograd, p. 4.

[8] Aničić, J., Popović, S. 2015. Koncept ABC metode, prednosti i ograničenja u primeni, Računovodstvo, No. 3: 68-79.

[9] Cantino, V. 2009. Korporativno uptravjanje, merenje performansi i normativna usaglašenost sistema internih kontrola, Data Status, Beograd.

[10] Damodaran, A. 2007. Korporativne finansije: teorija i praksa, Modus, Podgorica.

[11] Gritsenko O.I. and Skorba O.A. 2015. Internal business control of service quality costs: managerial aspect, Actual problems of economics, 3, p. 365-373.

[12] Panchuk P. 2015. Harmonization of accounting and taxation accounting at reporting formation on income. Actual problems of economy, p 373-379.

[13] Popović S. 2015. Implementacija heterogenih rizika u radu interne revizije, Revizor, 69, p. 7-19. 
[14] Popović S., Majstorović A., Grublješić Ž.2015. Valuation of facilities in use and application of international accounting standards, Actual problems of economy, p. 379-387.

[15] Popović, S.2015. Interna revizija kao pokretač finansijske analize u javnim preduzećima $R S$, Revizor, 72, p. 41-53.

\title{
INTERNA I EKSTERNA REVIZIJA KAO FAKTOR POBOLJŠANJA FUNKCIJE UPRAVLJANJA POLJOPRIVREDNOG PREDUZEĆA
}

\author{
Popović Slobodan ${ }^{1}$, Laban Bogdan ${ }^{2}$, Vukasović Dragan ${ }^{3}$, Ivić Mladen ${ }^{4}$, Nastić \\ Sanda ${ }^{5}$, Popović Vera ${ }^{6}$ \\ ${ }^{1}$ Docent, interni revizor, Fakultet za ekonomiju i industrijski menadžment, Cvećarska 2, \\ Novi Sad, R.Srbija \\ ${ }^{2}$ PhD, Gradska uprava Grada Subotice, Subotica, R.Srbija, \\ ${ }^{3}$ Vanredni profesor, Nezavisni Univerzitet Banja Luka, Veljka Mlađenovića 12e, 78000 \\ Banja Luka, Bosna i Hercegovina, \\ ${ }^{4}$ Vanredni profesor, University of Business Engineering and Management Banja Luka, \\ Faculty of Economics, 78000 Banja Luka, Bosnia and Hercegovina \\ ${ }^{5}$ PhD, JKP Vodovod i kanalizacija, Masarikova 17, 21000 Novi Sad, R.Serbia, \\ ${ }^{6}$ PhD, Institut za ratarstvo i povrtarstvo, M. Gorkog 30, 21000 Novi Sad, R.Srbija.
}

Sažetak: Revizija može da bude faktor i postavljen mehanizam podrške donošenja odluka menadžmentu. Time novine upotrebe revizije treba da doprinesu poboljšanju ukupnog rezultata upravljanja poljoprivrednim preduzećem. Osnovni cilj primene preporuka interne i eksterne revizije je smanjenje rizika po preduzeće na svim nivoima upravljanja. Rad ističe značaj uspostavljanja procesa kontrolnih mehanizmama, kojim će povećati sigurnost i bezbednost poslovanja preduzeća. Ukupna revizija može da pruže punu podršku upravljačkoj strukturi u nastojanjima povećanja sigurnosti i efikasnosti poslovanja, što je bitno u poljoprivrednoj delatnosti jer ista raspolaže sa sporim obrtom kapitala. Autori ističu da ne postoji opšte prihvaćeni model primene ponašanja menadžmenta po pitanju praktične primene revizijskih poslova koji se mogu uvesti u cilju povećanja efikasnosti poslovanja preduzeća. Time autori na konkretan način ističu značaj implementacije revizije u poljoprivredi jer ista može ostvariti benefite od uvažavanja revizijskih zaključaka.

Ključne reči: interna revizija, eksterna revizija, upravljanje, rezultati.

$\begin{array}{ll}\text { Prijavljen: } & 30.11 .2018 \\ \text { Ispravljen: } & 15.12 .2018 \\ \text { Prihvaćen: } & 18.12 .2018\end{array}$

